\title{
Társszakmák a lelki egészség szolgálatában
}

\author{
PINTÉR GÁBOR \\ Semmelweis Egyetem, Pet̋̋ András Kar, Humántudományi Intézet, Budapest \\ ELTE, Pedagógiai és Pszichológiai Kar, \\ Pszichológiai Tanácsadás Tanszék, Budapest
}

(Beérkezett: 2018. augusztus 1., elfogadva: 2019. március 4.)

Tanulmányunkban négy, egymáshoz több szempontból közel álló segítő szakmát tárgyalunk, ezek: a pszichológiai tanácsadás, a mentálhigiéné, a klinikai pszichológia és a pszichoterápia. Az adott szakma képzettséget szerzett gyakorlója: a tanácsadó szakpszichológus, a mentálhigiénés szakember, a klinikai szakpszichológus és a pszichoterapeuta (szakpszichológus vagy szakorvos). Munkánkban vázoljuk az adott szakma jogi, képzettségi hátterét, az elvárható kompetenciákat, a tevékenység legfontosabb területeit és az egyes képzési rendszereket. Sok szempontra igyekszünk figyelni, amikor összevetjük mindezeket. Az érett személyiség szintjeit, a beavatkozások hatótényezóinek rendszerét és a munkaformák különbségének főbb dimenzióit gondoljuk át. Főképp a tanácsadás és mentálhigiéné, illetve a tanácsadás és a pszichoterápia különbözőségével foglalkozunk. Végül néhány gondolatot fogalmazunk meg a tanulmányunkba bevont segító szakmák fejlődésének trendjeiról és az előttük álló feladatokról, valamint a köztük levő együttmúködés jelenéről és lehetséges jövőjéről.

Kulcsszavak: tanácsadás, mentálhigiéné, klinikai pszichológia, pszichoterápia, lelki egészség, segítő kompetenciák, a segítő tevékenységek területei, jogi háttér, képzési rendszerek, interdiszciplináris együttmúködés

\section{Bevezetés}

Carl Rogers 1942-ben megjelent úttörő könyvének címe: Counseling and Psychotherapy, azaz Konzultáció és pszichoterápia. Rogers alig különbözteti meg e fogalmakat, majdnem hogy szinonimaként használja őket. A későbbiekben már külön beszél tanácsadásról, amikor a pszichoterápia általános szakmai kritériumai is jobban körvonalazódnak, de akkor sem alakít ki élesen eltérő tanácsadási koncepciót. Az bizonyos, hogy Rogers a szúkebb értelemben vett, pszichológiai jellegú tanácsadásról beszél, csak az állhat ily közel a pszichoterápiához.

\footnotetext{
* Levelezési cím: dr. Pintér Gábor, Semmelweis Egyetem, Pető András Kar, 1125 Budapest, Kútvölgyi út 6. E-mail: pinter.gabor@semmelweis-univ.hu
} 
Ezt támasztja alá az is, hogy módszerét egyetemi tanszékeken dolgozta ki pszichológus oktatók és hallgatók körében: az ohioi, majd a chicagoi egyetem pszichológus professzoraként. Mindkét helyen tanácsadó központokat is szervezett a lakosság részére, ahol a terapeuták tanszéki munkatársai, a gyakorló terapeuták felsőbb éves pszichológia szakos hallgatói voltak, s a terápiás kutatásokat is ők végezték. Bár néhány évtizeddel előbb is volt már pl. pályaválasztási tanácsadás, s létezett a betegek lelki segítése is, a tanácsadás fejlődésére minden bizonnyal épp Rogers volt a legnagyobb hatással. Az encounter csoportokat is ez idő tájt hozta létre, amikor tömegesen kellett a sérült veterán katonák lelki ellátásáról gondoskodni

Történeti perspektívában a pszichoterápia módszerspecifikus iskolái által kifejlesztett elméletek és főképp módszerek hatoltak be az egészséges emberek és közösségek világába és szélesedtek ki abban. Jól látszik ez Carl Rogers életpálya fejődésén: érdeklődése a terápia felől a hatvanas években az egészséges ember fejlesztése felé fordult, s kiszélesedett minden alkalmazott területre (pl. oktatás, nevelés, munka, szervezetek). Pályája harmadik nagy szakaszában pedig az óriás csoportok világa került az érdeklődése középpontjába (kultúrközi kommunikáció). Tehát a gyógyítás felől megyünk a megelőzés irányába, egyre szélesebb területen. A pszichoterápiás iskolák, elméletek, módszerek tulajdonképpen kidöntötték a pszichoterápia merev falait.

A segító szakmák köre azóta szerencsésen kiszélesedett. Önálló szakmák alakultak, sokszor párhuzamos fejlődéssel, igen széleskörú tevékenységrendszert alakítva ki. Ugyanakkor a "terepen” a határok elmosódnak, bizonytalanság uralkodik az átlátható, jól megszervezett ellátás helyett. A lelki egészséget előmozdító tevékenységek jelentős részét a leghatékonyabban interdiszciplináris teamekben lehetne ellátni. Ezekben pszichológus, pszichoterapeuta, orvos, a segítő hivatásra képzett pedagógus, lelkész, védőnő, stb. dolgozhat együtt. Optimális esetben mindenki azzal foglalkozna, amihez ért, amit szeret, amit a képzettsége lehetővé tesz.

Tanulmányunkban négy, egymáshoz több szempontból közelinek mondható segítő szakmát állítunk egymás mellé, ezek: a pszichológiai tanácsadás, a mentálhigiéné, a klinikai pszichológia és a pszichoterápia. Mindegyikük jól definiált, hazai gyakorlatunkban széles körúen alkalmazott, $\mathrm{s}$ a nemzetközi gyakorlatban is általánosan elterjedt, ha nem is mindig azonos elnevezésekkel. A megszerezhető tudás konkrét képzési rendszerek keretében történik, a tevékenység és a képzés jogi háttere alap szinten biztosított. Ilyen értelemben valóban szakmának és elkülöníthető szakmának tekinthetők. Ugyanakkor a tevékenységrendszer, a gyakorlati megvalósulás, a szükséges kompetenciák és a képzési tartalmak többszörösen átfedik egymást, a terepen néha nem kevés nehézséget okozva. Ezért is szükséges, 
hogy összevontan foglalkozzunk velük. Jelen munkánkban igyekszünk sok szempontra figyelni, miközben bemutatjuk és összehasonlítjuk ezeket a segító tevékenységtípusokat, szakmákat.

Kezdetben a tanácsadásra fókuszáltam és szerettem volna összevetni azt a mentálhigiéné rendszerével. De minden területen újra és újra a klinikai pszichológia és a pszichoterápia világa került érintésre, vagy történeti szempontból, vagy valamely összehasonlításban. A sokszoros hivatkozás helyett úgy döntöttem, hogy ezt a két szakmát is bevonom az elemzésbe, előre számítva arra, hogy különösen a pszichoterápia esetében nem törekedhetek a bemutatás teljességére, csak egyfajta esszenciát próbálok majd vázolni.

Ugyanakkor tudjuk, hogy a segítő társszakmák száma sokkal nagyobb, mint amit jelen összehasonlító munkánkba be tudtunk vonni. Érdemes lenne ezeket is hasonló alapossággal, egy sokkal nagyobb volumenú kötetben bemutatni és összehasonlító elemzés alá vonni. Ezek közül két jelentős tudományterületet mindenképpen meg kell említenünk, mindkettő főképp a szomatikus betegségek problematikájához kapcsolódik: A magatartásorvoslás medicinális jellegú, inkább a gyógyításra és a rehabilitációra koncentrál, interdiszciplináris terület. A magatartás módosítása révén hat, erősíti a terápiák hatását, kóros viselkedésmintákat korrigál, magatartás szempontú betegvezetést alkalmaz (Kopp \& Buda, 2001). Az egészségpszichológia a prevencióra fókuszál jobban, fóképp a tanuláselméleteket és a kognitív megközelítést alkalmazza. Gyakori célja a károsító magatartás csökkentése, a konkrét szomatikus betegségekhez kapcsolódó egészségvédelem, az egészségfejlesztés, az életminőség általános és konkrét javítása (Urbán, 2017). A Szegedi Egyetem hároméves alkalmazott egészségpszichológiai szakpszichológus képzése ennek elméleti hátterét és kompetenciáit oktatja.

A segítő területen fontosak a szúkebb, körülírt alkalmazási területen munkálkodó szakmák is, ezek mélyebb elméleti és gyakorlati tudást képviselnek az adott problémakörben. Erre jó példa az addiktológiai konzultáns végzettség, amely Budapesten a Semmelweis Egyetem Egészségtudományi Karán szerezhető meg, három féléves szakirányú továbbképzési szakon. A speciális szakember jártas a családi életciklusok, krízishelyzetek, az addiktív viselkedésformák megértésében és segítésében a medicina és a prevenció területén. Egyéni, pár- és csoportos konzultációs munkájában felhasználja a pszichoaktív szerekkel és fogyasztásukkal kapcsolatos specifikus pszichológiai, egészségügyi, jogi és egyéb, multidimenzionális ismereteit. A lelki segítségnyújtás módszertani szempontból szúkebb területei pedig a pszichoterápiás iskolákhoz kapcsolódó (nem-pszichoterápiás) módszerspecifikus tanácsadói képzések, amelyek részletes bemutatásától szintén el kell tekintenünk. Leginkább a humanisztikus pszichoterápiák mentén bontakoztak ki jelentős segítő alkalmazások, a legkülönfélébb elnevezésekkel, például (zárójelben a 
teljes képzés megközelítő időtartama és óraszámai): személyközpontú tanácsadó (3 év, 400 óra), családterapeuta (3 év, 400 óra), pszichodráma vezetó (6 év, 800 óra), logoterapeuta (3 év, 500 óra). Mindezek át- meg átszövik a szakmai képzéseket és többször felbukkannak a jelen elemzésbe bevont négy segítő szakma képzési rendszerében is. Azon képzettségek presztízse magasabb a szakmában és még az állásinterjúkon is, amelyek akkreditált pszichoterápiás iskolához kapcsolódnak.

Az olvasó számára fontos lehet jelezni a szerző kapcsolódását a bemutatandó szakmákhoz: végzettsége alapján pszichológus (előzőleg kibernetikus mérnök), szakvizsgái szerint klinikai szakpszichológus és pszichoterapeuta, kiképzőként és szupervizorként dolgozik a személyközpontú pszichoterápiában és a pszichodrámában. A budapesti Pszichiátriai Klinika, majd az egykori HIETE Klinikai Pszichológiai tanszék munkatársaként részt vett a pszichoterápia és a klinikai pszichológia jelen akkreditációinak szakmai és szakmapolitikai megalapozási munkáiban (pl. az „alappszichoterápiás gyakorlat", csoportos szupervízió bevezetése, a személyközpontú pszichoterápia és pszichodráma módszerspecifikus oktatási modelljei). Ugyanakkor már a nyolcvanas évektól kezdve jelen van a hazai mentálhigiénés szakma kialakításánál és oktatóként sok évfolyamban folyamatosan részt vesz a mentálhigiénés képzésekben (Semmelweis Egyetem (SE) Pszichiátriai Klinika, SE Mentálhigiénés Intézet képzése és előzményei, KLTE Debrecen). Az ELTE címzetes egyetemi tanáraként kompetenciafejlesztó tréningeket dolgozott ki és tart a tanácsadó pszichológus szakképzésben. Főállásban a Semmelweis Egyetem, Pető András Kar, Humántudományi Intézet tudományos tanácsadója.

\section{Pszichológiai tanácsadás}

A tanácsadás fogalma tág értelemben igen széles körú tevékenységrendszert takar. Létezik mérnöki, ügyvédi, orvosi tanácsadás, s területünkön is sokféle: pályaválasztási, mentálhigiénés vagy párkapcsolati. A továbbiakban a szúkebb értelemben vett pszichológiai jellegú tanácsadásról beszélünk.

A „tanácsadás” fogalma a magyar nyelvben épp ehelyütt nem a legszerencsésebb. Tanácsot ritkábban kap, aki egy klasszikus segító kapcsolatba belép, inkább fontos életvezetési, döntési kérdéseinek konzultálását, lelki támogatást, mindenféle egyéb segítséget. Képzéseinken épp a direkt tanácsadás elkerülését tanítjuk. Bizonyos esetekben mégis szükség van rá, ahol egyfajta felvilágosító munkáról van szó (pl. drogambulancia). Itt nyilván inkább folyhat információközlés vagy konkrét tanácsadás is. 
A tanácsadás általában diádikus kapcsolati hatásokon keresztül valósul meg, ritkábban csoportos jellegú. Mindkettóben a kliens kerül a középpontba, az ő szükségletei alapján dolgozunk, természetesen nem adva fel a kapcsolat professzionális jellegzetességeinek kézben tartását. Az életvezetés előmozdítása, a megjelenő probléma közös megoldása a cél. A tanácsadás mindig folyamat, amely rendszeres találkozásokból áll, erre és a keretekre megállapodást kötünk. A zárt lélektani tér és az ehhez szükséges feltételek nélkülözhetetlenek.

A legtöbb tanácsadásban a segítő alapattitúdjei az empátia, feltétel nélküli elfogadás és kongruencia hármasát követik, akkor is, ha nem megnevezetten személyközpontú az irányultság. A pszichológiai tanácsadás legnyilvánvalóbb megkülönböztetô jellemzője, hogy pszichológusi alaptudásra épül.

A szakmai tevékenységet deklaráló jogi háttér: Tanácsadó pszichológusi tevékenységet „tanácsadó szakpszichológus” végezhet Magyarországon, a hasonló elnevezésú oklevél birtokában. Erről a képzettségről, amelynek formája szakirányú továbbképzés, az Oktatási Hivatal rendelkezik1.

A képzés kizárólag pszichológus alapdiplomára épülhet. Eddig és jelenleg is csak az ELTE PPK-n folyik ilyen szakképzés. A tanácsadó szakpszichológus végzettség a jogszabály szerint egyenértékú a pedagógus szakvizsgával (99/2014. Kormányrendelet²).

A különböző területeken dolgozó tanácsadó szakpszichológusokra e mellett természetesen a szakterületnek megfelelő törvényi szabályozás is vonatkozik. Ezek élesen különböznek és ráadásul különféle ágazatokhoz tartoznak (pl. a pedagógiai szakszolgálat vagy a katasztrófavédelem).

A tanácsadási tevékenység jellegzetességeinek tárgyalásával bőségesen találkozunk a hazai szakirodalomban. Ritoók (2009) a tanácsadást viszonylag rövid távú folyamatnak gondolja, alapvetően egészséges személyek számára, amely segít a problémamegoldásban, a cselekvésre fókuszál, célja a támogatás révén a viselkedés optimalizálása az adott helyzetben. Mindezt az iskolapszichológia szempontjából is vizsgálja (Ritoók, 2003, 2011).

Tringer (1998) kiemeli a pszichoterápia és a mentálhigiéné közös eredetét. Már azzal is állást foglal e mellett, hogy személyközpontú alaptankönyvének „A gyógyító beszélgetés” címet adja. Tárgyalja ennek tanuláselméleti és kommunikációs alapjait, s úgy definiálja azt, mint a személyközpontú pszichoterápia "gyermekét”, amely bármely segító hivatásban hasznosan alkalmazható.

1 Letöltve: 2019. 02. 25-én: http://ppkteszt.elte.hu/file/ismerteto_tanacsado_szakpszich_.pdf

2 Letöltve: 2019. 02. 25-én: http://www.budapestedu.hu/data/cms186921/MK_14_043.pdf 
Bagdy (2009) a tanácsadást bevonja azon munkaformák körébe, amellyel a segító foglalkozásúak dolgoznak. Részletesen elemzi a munkaformák hasonlóságát és kidolgozza az elkülönítéshez szükséges dimenziókat, amiről még beszélünk a késóbbiekben. A tanácsadás középpontjába állítja a problémafókusz átdolgozását, céljai közül kiemeli a szelftudatosság erősödését és a saját erő növelésének szerepét a különféle megoldásokban. Nyitrai (2013) a tanácsadó szakember feladatait foglalja össze, és a pszichoterápiával való kapcsolatot elemzi. A tanácsadás elsősorban döntési és egyéb általános képességeket fejleszt.

Pintér (2009) szerint a tanácsadási tevékenység, ellentétben a pszichoterápiával, nem gyógyító jellegú, nem a személyiség egészének összmúködésére és annak struktúrájára hat. A tanácsadás is kapcsolati megállapodáson alapul, de nem feltétlenül szükséges erős munkaszövetség kialakítása. A kapcsolati ajánlat itt általában konkrét célhoz kapcsolódik, ami lehet életeseményhez kapcsolódó probléma vagy döntési helyzet segítése, megküzdési potenciál növelése. Sok esetben a tanácsadás preventív jellegú segító kapcsolat, vagy konzultatív módon közös megoldáskeresés.

Kozékiné Hammer (2016) tanulmányában frappáns megoldást kínál a tanácsadó szakpszichológusok valós problémáinak megközelítésére és segítésére. Leírja az ideális szakembert (pl. jó önismeretet szerzett, képzett, tudás, tisztelet, türelem jellemzi), az ideális klienst (pl. motivált, önként jön, van belátási képessége, nyitott). Ezt követi az ideális munkahely és ideális tanácsadói beavatkozás felvázolása. Majd élethúen bemutatja a reális modellt is ugyanezen területeket számba véve. A különbség óriási, ami óhatatlanul a pályakezdő szakember csalódásához vezet, mert ő leginkább az ideálist ismeri, de a reálissal találkozik. Ezután a szerzó optimális modellt dolgoz ki, amelyben összeegyezteti az elvárásokat és a lehetőségeket.

A következő részben egy, a szakma számára nélkülözhetetlen, igényes új munkára irányítjuk a figyelmünket: ez a Pszichológiai Tanácsadás Szakmai Protokollja, a továbbiakban: Alapprotokoll (Kissné Viszket \& MogyorósyRévész, 2019), amelynek kidolgozására az ELTE PPK Pszichológiai Tanácsadás Tanszék keretében került sor. A tanácsadói folyamatról szóló fejezete már előzetesen megjelent (Kissné Viszket \& Mogyorósy-Révész, 2017). Az Alapprotokoll számos területen segít az eligazodásban.

A tanácsadó szakpszichológus leggyakoribb munkaterületei ezen Alapprotokoll szerint a következők: óvodák, iskolák, pedagógiai szakszolgálatok, családsegítő központok, speciális nevelőintézmények, felsőoktatási tanácsadók, munkaügyi és szociális központok, fegyveres és rendvédelmi szervek, lelki segélyszolgálatok, drogambulanciák, emberi erőforrás menedzsment területek, felnőttképzési területek, stb. Az életkori bontás alapján kliensként minden korosztály szerepel, de a hozzáférhetőség igen egyenetlen. 
A legtipikusabb „célcsoportok" szerint pedig: az egyéni, családi és csoportos tanácsadás, a krízisintervenció, katasztrófa- és traumakezelés, a terápiás motiváció kialakítása, a pszichológiai rendellenességek diagnózisához értékelő eljárások használata, a multikulturális tanácsadás, szervezeti és vezetôi tanácsadás, tréningek, szakmai szupervízió és tudományos kutatás. A tanácsadói fókusz alapján a leggyakoribbak a pályaorientáció, nevelési és felsőoktatási tanácsadás, kapcsolati problémák, életkrízisek, a gyász segítése, családi konfliktusok, válás, örökbefogadás, az időskor problémái, munkanélküliség, lelki egészségvédelem, szervezetfejlesztés (Kissné Viszket \& Mogyorósy-Révész, 2019).

A csoportos tanácsadás különféle alkalmazásai az egyéni pszichológiai tanácsadási folyamatok mellett mindenképpen egyre erősödő tendenciát mutatnak. Az első nagy lépés ebben vélhetően a pályaválasztási tanácsadás csoportos módszerének kipróbálása, kidolgozása és közreadása volt az ELTE keretében, módszertana szerint a Rogers-i megközelítés, a pszichodráma és a T-csoportok elemeinek integrálása által (Ritoók \& Pintér, 1987). Más területeken is fokozatosan nőtt az igény a csoportos tanácsadásra, akár az iskolákban, akár a szakszolgálatoknál. A tréningek elterjedésével a „csoportozás" szerencsésen behatolt a cégekhez, az önkormányzatokhoz, és a köztisztviselők - közalkalmazottak világába is. A növekvő igény természetesen a képzésekre is hasonló hatással volt.

A szakképzés megalapítása és évtizedeken át történő gondozása, fejlesztése legfőképp Ritoók Magda nevéhez fúződik. A kétéves képzés 1993-ban kezdődött az ELTE-n, kezdetben 25-35 hallgató részvételével. 2007-ben vált akkreditált képzéssé (Ritoók, 2009). A minden évben induló szakképzés mai létszáma már 120 fónél tart, s a túljelentkezés sem ritka. Mindez a társadalmi igény növekedését és a szakmapolitikai törekvések sikerét is jelzi, valamint jó visszajelzés a képzés értékességéről. Először a munka- és pályatanácsadási szakirány indult, ez később két területtel bővült: ezek a krízis és a családspecializációk. Az első tanév tematikája általános, a második év pedig a választott specializáció szerint halad. A képzést egyre inkább a gyakorlatorientáltság jellemzi, nagy hangsúly kerül mind a kompetenciafejlesztésre, mind a szupervízióra. A bemeneti követelmények közé szerencsés módon mára bekerült a legalább egy éves, szakmában eltöltött munkatapasztalat, a kimenetnél pedig kötelező a legalább 150 órás sajátélményú egyéni vagy csoportos tapasztalatszerzés valamely elfogadott módszerspecifikus irányzat szerint, pszichoterapeuta vezetésével.

Az Alapprotokoll alapján az 550 óra időtartamú, 4 féléves képzés főbb tartalmi elemeit említjük az alábbiakban. Elméleti ismeretek: a tanácsadás elméleti alapjai, egészségpszichológia, mentálhigiéné; szakmai etikai és jogi alapismeretek; pszichopatológia; elméleti bevezetés a családi tanácsadásba, 
a krízistanácsadásba, illetve a karrier-tanácsadásba. Szakmai gyakorlati képzés: a személyiség alkalmasságának fejlesztése (megfigyelés, tesztvizsgálatok), pszichológiai intervenció és önfejlesztés, a pszichodiagnosztikai módszerek alkalmazása a tanácsadásban, a tanácsadás szupervíziója, esetfeldolgozás, az egyéni és csoportos tanácsadás módszerei. Tanácsadás gyakorlat szakirányú gyakorlóhelyen. Ma is három specializáció választható: munka- és pályatanácsadás, családi és párkapcsolati tanácsadás, valamint krízistanácsadás. Az Alapprotokollban mindhárom szakirány tematikája megtalálható.

A mai képzés kifejezetten erős hangsúlyt helyez a csoportos tanácsadási lehetőségekre. Szinte minden elméleti és készségfejlesztő tárgyban megjelenik a csoport szempont, van külön „Csoportos tanácsadás” címú tantárgy, s minden specializáción megjelennek az adekvátan szükséges csoportos képzési tartalmak (például szülócsoportok, gyászfeldolgozó csoportok és pályacsoportok). Új elemként került a képzésbe a 2018. őszi évfolyamtól a nagycsoportos tapasztalatszerzés, amelyre a képzés legelején kerül sor, s így egyben a 120 fős évfolyam alapvető megismerkedési lehetőségét is megadja.

A tanácsadó szakpszichológusok szakképzésük mellett elvégezhetnek különféle, általuk szabadon választott egyéni vagy csoporthangsúlyú módszerspecifikus képzéseket. A pszichoterápiás egyesületek jelentős része tanácsadói/mentálhigiénés/ konzultáns „szakirányokat” is múködtetnek, amelyek ugyan nem adhatnak pszichoterápiás végzettséget, de teljes képzettséget sok esetben igen (pl. ",személyközpontú tanácsadó”, „pszichodráma vezető"). Ezek jelentôs elméleti tudást, módszertani bázist és kompetenciarendszert adnak az adott módszerben, jól kiegészítve a tanácsadói alapszaktudást.

A kompetenciák, tevékenységkörök bemutatása az Alapprotokoll egyik komoly vívmánya, ezért és tömörsége révén ezt kivételesen érdemes szó szerint idézni: „A szakképzést elvégző szakember

- a tanácsadás eszközeivel a pszichológia lehetőségeire támaszkodva segítséget tud nyújtani egyéni életvezetési problémák megoldásához, az életszerepek optimalizálásához, az emberi tanulás, kommunikáció, viselkedésváltozás, fejlődés elősegítéséhez;

- alkalmas a hagyományos tanácsadási módszerek alkalmazása mellett új szemléletú, az egyének és csoportok döntéseit, problémakezelési kompetenciáját, konfliktusmegoldó önállóságát és önfejlesztő képességeit is felszínre hozó tanácsadási feladatkör ellátására, az életvezetés egészét átfogó, illetve specializációjának megfelelő területeken: a pályaválasztási és pályaváltási döntésekben, a pályafejlődés támogatásában, a különféle életvezetési krízisek, valamint a családi és párkapcsolati problémák megelőzésében és megoldásában; 
- munkája során képes megfelelő módszerekkel adekvát információk gyújtésére a kliens szükségleteiről, képes interjúkkal, tesztekkel és a kezelés szempontjából releváns környezetben történő megfigyeléssel felmérni a klienst. Ennek ismeretében képes elfogadható és megvalósítható célok lefektetésére, megfelelő intervenciós lehetőségek kidolgozására és végrehajtására és olyan kritériumok megadásárára, amelyek segítségével a cél teljesülése később lemérhető;

- csoporttal dolgozva felmérést végez interjúkkal, tesztekkel és a szolgáltatás célterületén történő megfigyeléssel, melyek mentén megfelelő intervenciós lehetőségek kidolgozását és végrehajtását valósítja meg;

- szervezetet felmérő interjúkkal, kérdőívekkel, valamint egyéb olyan módszerekkel és technikákkal vizsgál, amelyek alkalmasak a szervezetnek a szolgáltatás célterületén történő tanulmányozására és megfelelő intervenciós lehetőségek kidolgozására és végrehajtására; ismeri a tanácsadás folyamatát, tudatos a folyamat lépéseinek meghatározásában, tudja, mikor kell beavatkozni és milyen szinten;

- feladata nem csak az aktuális résztvevőkkel való beavatkozás, hanem a beavatkozásnak tágabb rendszerben való szemlélése, képes a pszichoedukációra;

- kommunikációja világos és egyértelmú, pszichológiai véleményt tud készíteni adott formai és tartalmi szempontok alapján;

- ismeri saját kompetenciahatárait, szakmai szerepe van a kliens motiválásában, továbbirányításában megfelelő szakemberhez." (Kissné Viszket \& Mogyorósy-Révész, 2019).

A kutatások területén Kissné Viszket Mónika és Kiss Paszkál (2016) elvégezték a hazai képzésbe járók kompetenciavizsgálatát nemzetközi standardokat követve. A képzés jól láthatóan növeli a szükséges kompetenciákat. Szignifikáns különbség adódik minden évfolyam esetén a bejövő és a végzős hallgatók kompetencia-megélésében, például a következő területek kompetenciáiban: a tanácsadói interjú vezetése, a célok megfogalmazása, a tanácsadói helyzetfelmérés és diagnosztika területe, tanácsadói fejlesztés, a tanácsadói beavatkozás és a tanácsadói folyamat értékelése (Kissné Viszket \& Kiss, 2016). Ezt a munkát mindenképpen érdemes lenne folytatni és a kompetenciaterületek és szakmák vonatkozásában kiszélesíteni, akár a hiányzó kompetenciák hatásainak vizsgálatával is.

Az Alapprotokoll beszél a terület egyéb kutatásairól is, három ide tartozó kutatást is vázol, köztük az ELTE PPK Pszichológiai Tanácsadás Tanszékének kutatási törekvéseit, amelyeket ehelyütt nem tudunk bemutatni. Az összegzés viszont mindenképpen ide kívánkozik: „Összefoglalva a nemzetközi irodalmi tapasztalatok alapján elmondható, hogy a pszichológiai tanácsadás hatékony egészségmegőrző és gazdasági beavatkozás. A pszicho- 
lógiai tanácsadást vizsgáló tanulmányok általában magas szintú elégedettséget jeleznek az ügyfelek körében. Ezenfelül kutatási eredmények igazolják, hogy a tanácsadás fontos megelőző szerepet játszik a mentális betegségekkel kapcsolatban: a tanácsadás képes arra, hogy csökkentse a pszichiátriai szolgáltatásokra való igényt, megakadályozza a kevésbé súlyos problémák súlyosabbá válását, hogy segítse az embereket mentális egészségük javításában" (Kissné Viszket \& Mogyorósy-Révész, 2019).

Végül fontos még megemlítenünk, hogy az Alapprotokoll részletesen kitér a tanácsadási tevékenység etikai vonatkozásaira, az eszközhasználattal kapcsolatos normákra (tesztek jogtisztasága), valamint a pszichológiai tanácsadás ellátásához szükséges infrastruktúrára és a kapcsolódó adminisztrációs kötelezettségekre is.

\section{Mentálhigiéné}

A mentálhigiéné interdiszciplináris szemléleti és tevékenységrendszer, amelynek elsődleges célja a lelki egészség fejlesztése, ezen belül a megelőzés, a primer prevenció, de azon túlmenóen az aktív egészségfejlesztés is. Hazai kezdeményezői kezdettől fogva nem önálló szakmaként definiálták, s ezt a fontos jellegzetességét azóta is megtartotta. A képzés is a segító alapszakmákra épül, s a végzettség nem ad önálló alapszakmai jogosítványt. A szakember az eredeti szakterületén belül válik mentálhigiénés szakemberré.

Mindenképpen helyes és szükséges, hogy a mentálhigiéné esetében a lelki egészség oldaláról induljunk el. A Semmelweis Egyetem szakirányú továbbképzésének dokumentumában „a lelki egészség pozitív életérzéssel járó belső folyamategyensúly és ebból következő viselkedés, mely jelentősen hozzájárul az egyén belső stabilitásának biztosításához. A lelki egészség segítséget nyújt ahhoz, hogy az egyén - nehézségek, zavarok, terhelések, sőt olykor szomatikus betegségek és fenyegetettség közepette is - megtalálja helyét a társadalomban, és megfelelóen tudja kezelni azokat a nehézségeket és változásokat, melyeknek ki van téve. A mentálhigiéné a lelki egészségvédelem tudománya és szervezett gyakorlata, mely mind az egyént, mind a közösséget érinti: a lelkileg egészséges személyiség kialakítására, valamint a társadalom egészséges múködésmódjára irányuló erőfeszítések közös elnevezése" (Semmelweis Egyetem Egészségügyi Közszolgálati Kar, Mentálhigiéné Szakirányú Továbbképzési Szak, 2018-2020, Budapest³).

3 Letöltve: 2019. 02. 25-én: http://mental.semmelweis.hu/mellekletek/mental-doc/mentalhigi ene_SZTSZ_tanterv_tantargyiprogramok_mintatanterv_2018_04_oldalszamokkal_honlapra.pdf 
Sok szempontból nagy előny, hogy a mentálhigiénés szakember alapvetően megtartja saját hivatását, ehhez szerzi meg többletként elméleti és készségszintú tudását és új, prevenciós szemléletét. Ez azt jelenti, hogy a kliens nem egy számára ismeretlen szakma gyakorlójához kell, hogy elmenjen, például pszichológushoz, pszichiáterhez, távoli, ismeretlen helyre, helyzetbe. Ehelyett elmegy oda, ahová amúgy is menne: a pedagógushoz, orvoshoz, lelkészhez, aki jó esetben mentálhigiénés szakember is a maga szakterületén. Kiváló tanítványaink között akad például személyközpontú nőgyógyász, családorvos, jogász, szerzetes, utcai szociális munkás, tanító, nyelvtanár. Így könnyen jut el a segítség a rászorulókhoz. A mentálhigiéné interdiszciplináris gyakorlata tehát a lakossághoz közel viszi a prevenciót és az egészségfejlesztést, s így a segítség könnyen elérhetóvé válik sok ember számára.

Buda Béla számos munkájában áttekinti a mentálhigiéné fogalmi köreit és a mentálhigiénés mozgalom nemzetközi történetét, amelyben Beers munkásságára (1908) megy vissza. A hazai történetben kiemeli az egykori telefonszolgálatok, krízisintervenciós részlegek jelentőségét. Fontosnak tekinti az országos mentálhigiénés programok elindulását és a mentálhigiénés egyetemi képzés megalapítását és megszervezését. Hangsúlyozza a promóciós oldalt a prevención túlmenően: közösségfejlesztésre, kapcsolatépítésre, egészségfejlesztésre van szükség. Módszertani szempontból kiemeli annak pragmatikus jellegét (Buda, 1998).

Bagdy Emőke (2009) tanulmányában kiemeli a kilencvenes évek törekvéseit, például azt, hogy a Klinikai Pszichológiai Szakmai Kollégiumnak alapos munkával sikerült az akkori Egészségügyi Cselekvési Programokhoz megfelelő ajánlásokat adni. A mentálhigiéné ott tevékenykedik, ahol megjelenik a probléma, felismer és korrekciót ad. Nem pszichoterápia, de elókészítheti, kiegészítheti azt. A mentálhigiénés szakember új lélektani szaktudását ötvözi saját szakmája kompetenciarendszerével. A kliensek elakadásai, krízisei, zavarai így korai felismeréssel összességében adekvát ellátást kapnak. Az interdiszciplináris team munka és a módszertani sokszínúség alapvető jellegzetesség.

Tomcsányi Teodóra és munkatársai munkája összefoglalja a mentálhigiéné elméletét, a mentálhigiénés képzést és a gyakorlatot: mentálhigiéné az emberek szolgálatában (Tomcsányi, Grezsa, \& Jelenits, 2003). A szerzők hangsúlyozzák, hogy a mentálhigiénés szakember saját szakterülete alaptevékenységét végzi „mentálhigiénés többlettudás” birtokában, holisztikus látásmóddal, reflektíven és promotívan. Komoly szerepet kap az értéktöltöttség, az élet értelmességének keresése, a kapcsolati orientáció, a cselekvés támogatása, az önaktualizálás. A főbb készségek a Rogers-i alapkészségek, amelyek mellett az együttmúködés és a közösségfejlesztés kompetenciái is hangsúlyozódnak. Az interdiszciplinaritás itt is fontos szerepet kap. 
Ittzés (2013) szerkesztett kötetében a szerzők Tomcsányi Teodórának tisztelegnek, középpontba állítva a „mentálhigiéné a társadalom szolgálatában" kérdéskört, mint az ünnepelt életmúvének egyik legfőbb alkotását, mellyel hozzájárult a mentálhigiéné mint önálló tudományterület kidolgozásához. Az alcím is erre utal: Cura mentis - Salus populi (a lélek gondozása - a nép java).

A továbbiakban a mentálhigiéné színtereit vesszük sorra (Pintér, 2005). A legfőbb színterek és feladatok:

A család területén: szülésre való felkészítés, házassági problémák, krízisek, válás, nevelőszülőség, örökbefogadás, kismamák problémái, a korai anyagyerek kapcsolat segítése, veszélyeztetett gyerekek, ifjak, egyedülállók problémái, a halálra történő megfelelő felkészítés.

Az oktatás területén: nevelési problémák, viselkedészavarok megelőzése, tanulási zavarok, pályaorientáció, nevelési tanácsadás, tanárok segítése, tantestületek segítése.

Az egészségügy területén: szerabúzus szempontjából veszélyeztetettek, AIDS-re veszélyeztetettek, a fogyatékossággal élők egyes csoportjai, krónikus betegséggel élők gondozása. Az életmód, túlsúly, abortusz, meddőség, mesterséges megtermékenyítés kérdéskörei. Kórházi adaptáció, kórházi mentálhigiénés gondozás.

Szociális területeken: a szociális ellátás teljes spektruma, a speciális csoportokhoz tartozók segítése, a munka világában a munkanélküliek problematikája, a munkahelyi egészségvédelem. Felnőtt és fiatalkorú búnelkövetők mentálhigiénés ellátása, a búnmegelőzés széles területe. Fegyveres testületek speciális mentálhigiénés problémái.

A krízisintervencióban: sürgősségi ellátás, kríziskezelés face to face helyzetben vagy például telefonos lelki elsősegély keretében.

Az igazságügyben: a mediáció területén, ahol a résztvevők az ellentétes nézeteket képviselö, ellentétes érdekú felek és a mediátor: peres ügyekben, a válások és más válsághelyzetek „menedzselése” területén és a gyermekvédelemben.

A csoportok területén: mesterséges, speciális, általában kisméretú csoportok létrehozása és múködtetése. Önismereti csoportok, önsegítő csoportok, szervezése, segítése, múködtetése.

A természetes közösségek területén: a „közösségi mentálhigiéné” területei, bölcsődében, óvodákban, iskolákban, vallási és kulturális intézményekben, munkahelyi mentálhigiéné, emberi erőforrás fejlesztés, pályaalkalmasság problémái. Lakóhelyi közösségek, egyházközösségi csoportok segítése.

A mentálhigiénés tevékenységek egy lehetséges rendszerbe foglalásának vázát adjuk most közre. A részletes anyag is hozzáférhető, amely ugyan a klinikai pszichológia szemszögéből íródott, de alapvetően interdiszciplináris módon a mentálhigiéné egészére érvényes (Pintér, 2005). Történeti szem- 
pontból ugyanis e tevékenységek kezdetben fóképp a klinikai szakpszichológusok vállalt feladatai voltak, mára viszont a mentálhigiéné széles szakmarendszere nagyrészt átvette őket (ugyanakkor természetesen a klinikai lélektannak is bőven maradtak feladatai). Egykori mentálhigiénés kurzusaink, képzéseink kiváló hallgatói ma már sokan például egyetemi, tanszéki munkatársak, fóállású vagy felkért oktatók. A tevékenységek egy lehetséges csoportosítása a következő:

I. Közvetlenül a kliensekkel végzett tevékenységcsoport

1. Diagnosztikai jellegú tevékenységek

2. Segító kapcsolat, „,konzultáció”: egyén, pár, család számára

3. Speciális területek (pl. fogyatékossággal élő gyermekek szüleinek csoportja)

4. Krízisintervenció

5. Mediáció

6. „Mesterséges" csoportok létrehozása és vezetése

7. Természetes közösségek, csoportok mentálhigiénés gondozása, segítése

II. A segitókkel, mentálhigiénés szakemberekkel végzett tevékenységcsoport

1. Egyéni konzultációk

2. Mentálhigiénés teamek segítése

3. Szupervízió biztosítása

4. Mentálhigiénés képzések, továbbképzések szervezése és az azokban történő oktatás

III. A társadalmi méretü mentálhigiénés munkában végzett tevékenységcsoport

1. Ismeretterjesztés, lelki egészségre nevelés

2. Mentálhigiénés ellátó rendszerek, alrendszerek szervezése és múködtetése

3. Egyetemi szintú posztgraduális képzések: szakalapítás, akkreditáció

4. Tudományos kutatások, szúrési programok

5. Szakmapolitikai munka a mentálhigiéné ügyéért

Fejezetünk további részében a mentálhigiénés képzés néhány jellegzetességét mutatjuk be. Grezsa (2013) foglalja össze a képzés történetét: A Magyar Pszichiátriai Társaság Pszichohigiénés munkacsoportja 1982-ben alakult (Tomcsányi Teodóra vezetésével akkor négyen alapítottuk meg), s elindította a „Lelki jelenségek és zavarok” címú sorozatát humán segítő diplomások számára. Tomcsányi Teodóra benyújtotta a Klinikai Szakmai Kollégium, majd az Országos Szakképzési Bizottság számára a posztgraduális egyetemi képzés tervezetét. Az első hosszabb kurzus 1987-ben indult, az elsó okleveleket pedig 1990-ben a Testnevelési Egyetem állította ki. Késóbb beindult 
Szegeden is ugyanezen képzés Ónody Sarolta vezetésével. Közben a Semmelweis Egyetem Pszichiátriai Klinikán is folyt komoly (de nem oklevelet adó) mentálhigiénés képzés, amely Tringer László „laikus” segítőkkel végzett évtizedes munkájából nőtt ki. A kilencvenes években már Debrecenben is megindult a képzés Bagdy Emóke és Bugán Antal vezetésével, s később például a Károli Gáspár Református Egyetemen is. A fent nevezett képzések magas minőségi színvonala garancia a mentálhigiéné mint szemlélet, interdiszciplináris tudomány és praxis magas színvonalú fejlődésére.

A Tomcsányi Teodóra és munkatársai nevével fémjelzett képzés ma a Semmelweis Egyetemen múködik, a Mentálhigiénés Intézet valósítja meg. A szakirányú továbbképzés neve: Mentálhigiéné szakirányú továbbképzési szak, a szakképzettség oklevélben szereplő megnevezése: mentálhigiénés szakember. A képzés bemenete legalább alapképzési szakon szerzett diploma humán segítő képzési területen.

A szakindítási dokumentum szerint: „A képzés célja a segítő foglalkozásúak szemléletének alakítása annak érdekében, hogy tágabb kontextusban tudjanak rálátni önmagukra, családi rendszerükre, munkájukra, szervezetükre és társadalmi helyükre. Ezt szakmai önismeretük mélyítésével, más szakterületek lelki egészségre vonatkozó tartalmainak tevékenységükbe történő integrációjával, a szakember-együttmúködések megteremtésével, a társadalmi folyamatok megismerésével és a mindezzel járó szemléletváltozással éri el.

A képzés célja továbbá a társadalom komplexitásának megtapasztalásán keresztül a résztvevők kommunikációs kultúrájának és konfliktuskezelő képességének változása, egy adott szervezeten belüli folyamatok mentálhigiénés szemléletú interveniálása. Elméleti ismeretek, stratégiák alkalmazásának elsajátításán keresztül olyan kompetenciák szerzése, amelyekkel javítani tudják az ember életét elkísérő formális és informális szervezetek (kórház, iskola, vállalati szféra stb.) egészséges múködését, és befolyásolni tudják a munkahelyi viselkedést: a dolgozók egyéni fejlődése, a munkahelyi közérzet, a szervezet hatékonyságának és életképességének javítása érdekében". ${ }^{4}$

A szakképzettség szempontjából meghatározó ismeretkörök: társadalomismeret, személyiséglélektan, a mentálhigiéné stúdiumai (nagy óraszámban), sajátélmény és önismereti stúdiumok (nagy óraszámban), tevékenységkísérés és kutatási módszerek.

Fontos további lépés, hogy ugyanitt időközben megalapításra és elindításra kerülhetett a mentálhigiénés lelkigondozó szak is.

4 Semmelweis Egyetem Egészségügyi Közszolgálati Kar, Mentálhigiéné szakirányú továbbképzési szak 2018-2020. Mintatanterv és tanulmányi tájékoztató. Letöltve: 2019. 02. 25-én: http:// mental.semmelweis.hu/mellekletek/mental-doc/mentalhigiene_SZTSZ_tanterv_tantargyi programok_mintatanterv_2018_04_oldalszamokkal_honlapra.pdf 
A mentálhigiénikus szakemberek a fent említett képzésük mellett vagy után elvégezhetnek különféle, általuk szabadon választott módszerspecifikus képzéseket, amelyek ugyan nem adhatnak pszichoterápiás végzettséget számukra sem, de teljes képzettséget több módszerben igen (példaképpen: „személyközpontú tanácsadó” vagy „pszichodráma vezető”).

\section{Klinikai szakpszichológia}

A klinikai szakpszichológia a medicinális alapszakvizsgák rendszerében megszerezhető önálló szakma, 1997-től elnevezése klinikai és mentálhigiéniai szakpszichológia. A képzés pszichológus alapdiplomára (MA) épül, 8 félév időtartamú, és az orvosegyetemekhez rendelt (vagy azokkal szoros együttmúködésben szervezhető). Budapesten például a nagy hagyományokkal rendelkező Klinikai Pszichológiai Tanszék a felelőse, de a Pécsi és a Debreceni Egyetemen is nagy népszerúségnek örvend. Mindenhol szükséges legalább 150 óra egyéni vagy csoportos sajátélmény megszerzése, bármely akkreditált módszer kiképzőjénél.

A tevékenység jogszabályi alapja a ma hatályos 1997. évi Egészségügyi Törvényben van lefektetve (1997. évi CLIV. törvény az egészségügyről ${ }^{5}$ ). A 103. §-ban szerepel: „A klinikai szakpszichológiai tevékenység az a klinikai és mentálhigiéniai szakpszichológus által végzett tevékenység, amely

a) a lelki egészség megőrzésére, fejlesztésére és helyreállítására,

b) a lelki zavarok megállapítására, vizsgálatára és okainak feltárására,

c) egyes betegségek diagnosztizálásához szükséges pszichodiagnosztikai vizsgálatok végzésére, valamint

d) a lelki zavarok pszichológiai módszerekkel történő korrekciójára irányul."

A fél évszázadra visszanyúló hazai klinikai pszichológia 1981-ben indította el szakirányú szakképzését, amely azóta jelentősen átalakult és tartalmi és formai szempontból is kiszélesedett. Az első szakmai protokollt 1998ban készítettük, amely 2005-ben megújulhatott. A sokszerzős, szinte minden medicinális szakterületre kiterjedő vaskos kötet (Bagdy \& Túry, 2005) már 27 fejezetben tárgyalja és foglalja rendszerbe a klinikai pszichológia szakmai irányelveit (például a pszichiátria, neuropszichológia, belgyógyászat, kardiológia, fogászat, mentálhigiéné területén).

Történeti szempontból a hazai klinikai pszichológia szorosan beágyazódott a magyar egészségügybe. A klinikai (szak)pszichológusok és a pszichiáterek fej-fej mellett haladtak a pszichopatológia és a pszichoterápia terüle-

5 Letöltve: 2019. 02. 25-én: https://net.jogtar.hu/jogszabaly?docid=99700154.TV 
tén, közösen dolgoztak a klinikákon és kórházakban, továbbképzésük részben együtt történt, s az oktató teamekben is együtt dolgoztak. Így a klinikai pszichológia a medicina szerves és elválaszthatatlan része lett, érthető, hogy a szakképzés akkreditációja is az ennek megfeleló (egészségügyi) keretben történt, a közel 60 medicinális szakvizsga egyike lett. Mint alapszakvizsga, amely az orvosi ágakban 5 év időtartamú, ez sem lehetett sokkal rövidebb, így lett négy éves az 1980-as években még rövidebb képzés, természetesen megnövelt tartalommal. A Klinikai Pszichológiai Szakmai Kollégium folyamatos küzdelmet folytatott a szakmai célok megvalósítása érdekében, néha több, néha kevesebb eredménnyel. Ez a történeti fejlődés sajnos hátrányokat is jelentett a szakma egésze számára, a pszichológus diplomára épülő szakképzések egységességének lehetősége ugyanis ezzel megszúnt, már csak azért is, mert más ágazati szabályozás (minisztérium) és akkreditációs rendszer alá került a klinikai pszichológia. Ugyanakkor megmaradt a pszichoterápia szabályozásának egységessége az orvos-pszichológus viszonylatban.

A klinikai szakpszichológusi szakma önállóan végezhető tevékenységrendszer, akár az állami egészségügyben, akár önálló magánrendelés formájában (30/1989. SZEM rendelet az orvosi, a klinikai szakpszichológusi, illetve az egyéb egészségügyi és szociális tevékenység gyakorlásáról'). Részét képezheti egy kívánatos interdiszciplináris együttmúködésnek, amelyben szakorvosok, mentálhigiénés szakemberek, tanácsadó szakpszichológusok, sokszor lelkészek, szociális munkások, fejlesztó pedagógusok is részt vesznek.

A klinikai szakpszichológus tevékenysége a primer, szekunder és tercier prevencióra is kiterjed. Elsődleges szakterülete a medicina teljes spektrumában végzett pszichodiagnosztikai, korrekciós és rehabilitációs tevékenységek komplex rendszere. Koherens elméleti alapon érti a személyiség strukturális felépítését, szerveződésének és múködésének dinamikáját, az egészséges viselkedésirányítás mikéntjét, s a patológiás szerveződések és múködések megjelenési formáit és lehetséges okait. Ismeri a lelki zavarok keletkezésének okait, széleskörú pszichopatológiai és pszichodiagnosztikai ismeretekkel rendelkezik. A hibás viselkedés egyedi megjelenési formáit kapcsolatba tudja hozni a lelki zavarok okaival, s ennek nyomán dönteni tud a korrekció lehetőségeiről: képes tudományos alapon, differenciáldiagnózis alapján indikációk és kontraindikációk kidolgozására. Elméletben ismeri az egyes pszichológiai és pszichoterápiás intervenciók, illetve módszerek hatótényezőit, a konkrét esetekben várható eredményességét. Jó néhány módszert a gyakorlatban is képes alkalmazni. Képes klinikai pszichológiai és határterületi tesztek összeállítására, validálására, szúrővizsgálatok tervezésére. Képes szakterületén önálló kutatás, például hatékonyságvizsgálat

6 Letöltve: 2019. 02. 25-én: http://jogiportal.hu/index.php?id=yech21692r57zpx8n\&state=1996 0725\&menu=view 
tervezésére és lebonyolítására. Képes a lélektan egyes fejezeteinek oktatására, és adott gyakorlati módszerek megfelelő továbbadására is (Pintér, 2005).

Ugyanitt olvashatunk a klinikai szakpszichológusok primer prevencióban végzett több tucatnyi tevékenységeleméről. A klinikai szakpszichológus a prevenciós team egyik résztvevője. Sok esetben kiemelt, szervező, vezető szerep jut számára, amelynek részben történeti okai vannak. A mentálhigiénés tevékenységek jelentős része a klinikai lélektanban már régen alkalmazott módszerek ismeretét és gyakorlatát igényli, sokszor hasonló, sok esetben adaptált formában. A klinikai lélektannak és múvelőinek Magyarországon is kezdeményezó szerep jutott a mentálhigiénés tevékenységek, szolgáltató rendszerek megszervezésében, a mentálhigiénés képzések elindításában (Pintér, 2005).

A szekunder és tercier prevencióban a klinikai szakpszichológus feladata a már kialakult betegségek, viselkedészavarok pszichés oldalának megértése és részletes diagnosztikája, kompetenciájának megfelelő mértékben szakértő korrekciója vagy annak segítése, minden orvosi szakágban a beteg lelki tényezőinek erősítése, a rehabilitációban való részvétel.

A pszichoterápia területén képzett klinikai szakpszichológus jogosult ún. "alap-pszichoterápia” végzésére. Az alap-pszichoterápiákat részletesen felsorolja a Pszichoterápia Szakmai Protokollja (Harmatta, Bagotai, Kurimay, Pintér, \& Vértes, 2005). Az ebben szereplő négyféle tevékenységtípus és a definiált tevékenység a következő:

\section{Pszichoterápiás krízisintervenció}

Tevékenység: pszichés tekintetben veszélyeztetó állapotban lévő személy(ek) célzott vizsgálata és kezelése, amelynek célja a veszélyeztetó állapot megszüntetése, illetve megfelelő szakmai ellátása.

\section{Pszichoterápiás konzultáció}

Tevékenység: egy adott probléma vagy tünet rövid távú megszüntetése pszichoterápiás eszközök felhasználásával.

\section{Szupportív terápia - pszichoterápiás betegvezetés}

Tevékenység: pszichoterápiás szemlélettel vezetett célzott beszélgetések, amelyek a beteg problémáinak felismerését, életvezetési nehézségeinek megoldását, egyéb kezeléseinek segítését és kiegészítését szolgálják. Csatlakozhat osztályos vagy ambuláns pszichoterápiához is, követési jelleggel.

\section{Autogén tréning}

Tevékenység: testi múködések tudatosítása és harmonizálása meghatározott gyakorlatsorozat alkalmazásával, amely során feltételes reflexek épülnek ki. A gyakorlatsor elsajátításával a pszichés tenzió csökken, a szorongás oldódik, a vegetatív múködés stabilizálódik. 
A klinikai szakpszichológus alap-pszichoterápiákon túlmutató terápiás tevékenységre jogszabály szerint akkor jogosult, ha ráépített pszichoterapeuta szakvizsgát is szerez. Ezzel együtt, vagy ez után szerezhet módszerspecifikus pszichoterápiás végzettséget (pl. személyközpontú pszichoterapeuta, családpszichoterapeuta, integratív pszichoterapeuta, pszichodráma pszichoterapeuta, stb.). A képzés lezárásához szükséges sajátélményú rész elvégzése mindebből a szakvizsgára bocsátáshoz köztelező. A gyakorlatban a fenti szintek elhatárolása érthetően nem éles, a dolog természetéből fakadóan. Ugyanakkor sok esetben túlzott mértékben összekeverednek, káoszt és esetleg felelőtlen veszélyeztetést okozva.

\section{Pszichoterápia}

A pszichoterápia világának részletes bemutatására, ahogy már a bevezetőben jeleztük, nem vállalkozhatunk, sem terjedelmi okokból, sem munkánk célját tekintve. Csak egyfajta esszenciát adhatunk, amely a fent tárgyalt szakmákkal történő összehasonlítását alapszinten lehetóvé teszi.

A pszichoterápiás tevékenység alapja is a hatályos Egészségügyi Törvényben van lefektetve, ugyancsak a 103. paragrafusban, amely jogi szempontból definiálja és deklarálja a pszichoterápiát:

„A pszichoterápia többféle módszeren alapuló, tudományosan megalapozott, a pszichés és pszichoszomatikus zavarok esetén alkalmazott, egyéni vagy csoportos formában, több, meghatározott időtartamú ülésben történő terápiás eljárás, amelyet a pszichoterápiás eljárások végzésére képesítéssel rendelkező szakorvos vagy klinikai szakpszichológus végezhet önállóan" (1997. évi CLIV. törvény az egészségügyről7).

A pszichoterápia egységes, konszenzuson alapuló definíciója nem áll rendelkezésre, de abban szakmai egyetértés van, hogy célja gyógyító jellegú, eszköze a közvetlen emberi kommunikáció, s két vagy több személy között zárt lélektani térben történik. A tudományos pszichoterápiák hátterében koherens elméletek állnak a személyiség elméletéről és múködéséről, a személyiségfejlődés elakadásairól, a korrekció lehetőségeiről és módszereiről.

A hazai pszichoterápiás módszereket a Pszichoterápiás Tanács fogja öszsze, melyet csaknem harminc éve, 1991-ben alakítottuk meg, az akkor prosperáló tízféle irányzat egyesületeinek vezetőiként. A pszichoterápiás módszerspecifikus irányzatok tudományos hátterét összefoglaló első kötet is ezeket a módszereket fogta egybe (Pintér, 1993). A Tanács azóta folyamatosan képviseli a pszichoterápiát, fellép annak közös ügyeiért, összefogja

7 Letöltve: 2019. 02. 25-én: https:// net.jogtar.hu/jogszabaly?docid=99700154.TV 
a terápiás iskolákat. Hivatalos „,bekötöttsége” a Pszichiátriai, valamint a Klinikai Pszichológiai Szakmai Kollégium keretében történt mint azok állandó bizottsága. A jelentkező új módszerek csatlakozási eljárása is kidolgozásra került.

A pszichoterápia medicinális jellege a történeti fejlődésben folytatja azt az utat, amelyet a klinikai pszichológia esetében az előző alfejezetben vázoltunk. A nyolcvanas években megszerezhet” „pszichoterapeuta” címet pszichiáterek és más szakorvosok számára 1993-ban, klinikai szakpszichológusok esetében 2000-ben felváltotta a "ráépített szakvizsga”. A képzés és a vizsga szabályozásának mindenben követnie kellett a medicinális szakvizsgákra általában vonatkozókat. Ez a szakma presztízsét tekintve, az orvospszichológussal együttmúködésben, a továbbképzésekben, az egészségügyi gyakorlatban mindenképpen előnyt jelent. Jelentős kivétel, hogy nem orvosi alapdiplomával orvosi szakvizsgát lehessen tenni. Ugyanakkor ennek ára, hogy tovább csökkentette a pszichológia egységes szabályozásának lehetóségét, s az is, hogy a pszichoterápiás képzés ügye kizárólag a medicina és az egyetemi autonómia körébe került, amelyet sokan kifogásolnak.

Az önálló szakmai protokoll kötetet több éves munkával a kétezres évek elején dolgoztuk ki, a módszerspecifikus pszichoterápiás egyesületek közremúködésével (Harmatta és mtsai, 2005).

A protokoll szerint „egyéni, illetve csoportos pszichoterápia alatt a hazánkban elterjedt, képzéssel és megfelelő szintú képviselettel rendelkező, tudományosan megalapozott módszerspecifikus pszichoterápiákat értjük. A protokollban azon pszichoterápiák szerepelnek, amelyek klinikai értelemben önmagukban fó terápiáként alkalmazhatók, a hazai klinikumban elterjedtek, a Pszichoterápiás Tanácsban és a hazai pszichoterápiás képzési rendszerben részt vesznek. Az eljárások sora nem végleges, későbbiekben további eljárások akkreditálhatók, amennyiben a fenti követelményeknek eleget tesznek" (Harmatta és mtsai, 2005, 287. o.).

A pszichoterápiás képzettség és tevékenység egymásra épülő szintjei a következők: 1. alap-pszichoterápia 2. pszichoterápia 3. szakpszichoterápia.

$\mathrm{Az}$ „, alap-pszichoterápiát” már említettük, amelyet klinikai szakpszichológusok és pszichiáter szakorvosok végezhetnek, mivel mindkét szakképzésben ennek tartalma szerepel a kimeneti követelményekben. „Pszichoterápia” végzéséhez ráépített szakvizsgaként akkreditált pszichoterápiás szakvizsga szükséges, amely jelenleg a szakorvosi, illetve klinikai szakpszichológusi, neuropszichológusi vagy alkalmazott egészségpszichológusi alapszakvizsgákra építhető. A szükséges módszerspecifikus fázis az akkreditált módszerspecifikus irányzatok bármelyikében elvégezhető, ezek sajátélményt, elméletet, módszertani képzést és szupervíziót tartalmaznak (általában a szakvizsga szint kb. 400 óra). „Szakpszichoterápia” (módszerspecifikus pszichoterápia) végzéséhez pszichoterapeuta szakképesítés és valamely módszerben való teljes módszerspecifikus képzettség szükséges. 
A pszichoterápia néhány fontos vonása, amelyet a Szakmai protokoll (Harmatta és mtsai, 2005) is kiemel: A pszichoterápia mindig kezeléssorozat, ülésekben történik. Az ülések gyakorisága és időtartama előre rögzített. A terápiára történő megállapodás és a beteg kellő informálása nélkülözhetetlen. Az eljárás csak önkéntes alapon végezhető. A terápia egyik fő gyógyító tényezője maga a kapcsolat, így a terapeuta személyisége döntő a folyamatban. A pszichoterápia ambuláns és kórházi kezelésként alkalmazandó. A pszichoterápiás eljárások meghatározott esetekben egymással, illetve gyógyszeres terápiával kombinálhatók. A szakpszichoterápia pedig, amely a képzésben és a finanszírozási rendszerben is a legmagasabb helyet foglalja el, a pszichoterápiás ráépített szakvizsga után megszerzett teljes módszerspecifikus végzettséget foglalja magában. Részletes leírásukat a protokoll kötet tartalmazza.

A hazai gyakorlatban leggyakrabban alkalmazott, a finanszírozási rendszerben is szereplő és a képzési rendszerben is akkreditált szakpszichoterápiák szerencsésen egybeesnek. Ma 15 módszer reprezentáns egyesületei alkotják a „Pszichoterápiás Tanács Szövetséget”. Jogi formája szintén egyesület, így döntési jogköre nincs. Ennek ellenére munkája ma is jelentős. Fontos tény ezzel kapcsolatban, hogy az Orvosegyetemek Pszichoterápiás Grémiumai (ahol a döntési jogkör egy része van) ma is elfogadják a történetileg kialakult konszenzust. Így a pszichoterápiás ráépített szakképzésben ezen módszerek ekvivalens módon választhatók (például pszichoanalízis, kognitív és viselkedésterápia, személyközpontú pszichoterápia, pszichodráma, családterápia, stb.). A pszichoterápiás szakvizsgához szükséges módszerspecifikus fázis általában rövidebb, mint a teljes szakpszichoterápiás képzés az adott módszerben (például a pszichodrámában 410 óra a 760 órás teljes „pszichodráma pszichoterapeuta” képzési programból).

Természetesen a képzés egészében a pszichoterápia általános elmélete és gyakorlata, valamint alapszinten az összes módszer mindenki számára bemutatásra kerül. A klinikai gyakorlat pszichiáterek és klinikai szakpszichológusok számára egységesen 24 hónapos. Európai képzettségi szint az Európai Pszichoterápiás Szövetség által adott ECP fokozat (European Certificate for Psychotherapy), ez a Pszichoterápiás Tanács Szövetségen keresztül szerezhető meg.

A szakorvosok és klinikai szakpszichológusok a történetileg kialakult gyakorlatnak megfelelően ma is közös csoportokban képződnek, s az oktatók és a vizsgáztatók is a két csoportból integráltan kerülnek ki. 


\section{A bemutatott segítő szakmák összehasonlító elemzése}

A szakmák törvényi-jogi szabályozása mára meglehetősen egyértelmú. Ez több évtizedes szakmai - szakmapolitikai munka eredménye, amely nem volt mentes vitáktól és ma sincs konszenzuális egyetértés minden területen.

A tanácsadó szakpszichológus komplex tudását minden esetben MA pszichológus diplomára építi, s szakirányú továbbképzés keretében szerzi meg azt. Végzettsége jogi szempontból egyenértékú a pedagógus szakvizsgával, aminek fóképp a közoktatás területén számos előnye van. Több módszerspecifikus irányzatban szerezhet e mellett kiegészítő elméleti és módszertani tanácsadói többlettudást.

A leendő mentálhigiénés szakember segítő foglalkozású alapdiplomával beiratkozhat az egyetemi mentálhigiénés képzésbe, amelynek formája szakirányú továbbképzés. A mentálhigiénés szakember nem új szakmát kap a kezébe, hanem saját eredeti szakterületén válik mentálhigiénikussá, a szerzett tudás, gyakorlati kompetencia és attitűdök révén. Ô is részt vehet különféle módszerspecifikus tanácsadói szintú képzésekben.

A klinikai (és mentálhigiéniai) szakpszichológia önálló szakma, minden esetben MA pszichológus alapdiplomára épül. A szakember végzettségét a medicinális szakvizsgák rendszerébe tartozó szakvizsga jelenti. Többek között diagnosztikus, egészségfejlesztő és alap-pszichoterápiás jogosultsága van.

A pszichoterapeuta szakpszichológus medicinális ráépített szakképzés keretében szerzi meg pszichoterápiás tudását, amelynek végén ráépített szakvizsgát szerez. Alapszakvizsgája a jelen szabályozás (22/2012. (IX. 14.) EMMI rendelet ${ }^{8}$ ) szerint klinikai szakpszichológus, neuropszichológus, vagy alkalmazott egészségpszichológus lehet. A pszichoterapeuta szakképzés bemenete szakorvos esetében bármilyen klinikai orvosi alapszakvizsga lehet.

A gyakorlatban sokkal kevésbé jelentkeznek éles határok a segítő szakmák között, ennek előnyeivel és hátrányaival. Az egészség-betegség között sem lehet minden esetben egyértelmú határokat vonni a lelki zavarok területén. Már a neurotikus és a sine morbo múködés elkülönítése is nehéz, s leginkább definíció kérdése, hogy a lakosság 5 vagy akár (egyes vizsgálatok szerint) 30 százaléka sorolódik a neurotikus formakörbe. Ezen a problémán nem segített a neurózis óriási kategóriájának megszüntetése, tudományos szempontból egyébként örvendetes szétdarabolása sem. Nem csoda, hogy a tanácsadás és a pszichoterápia szétválasztása sem könnyú.

8 Letöltve: 2019. 02. 25-én: https://net.jogtar.hu/jogszabaly?docid=A1200022.EMM 
Részletesebb vizsgálódásunkat - a kliensre vonatkoztatva - az érett személyiség oldaláról indítjuk, amelynek elómozdítása minden bizonnyal közös nevezője a segítő beavatkozásoknak. Tehát nem a személyiség átalakításáról, s végképp nem a személyiség struktúrájának terápiás megváltoztatásáról beszélek, ha mind a négy szakma benne van a perspektívánkban. Minden kis lépés hasznos lehet a lelki érettség és egészség felé vezetó úton, bármely alábbi szegmens keretében. Az érett személyiség megfelelő belső pszichés funkciókkal rendelkezik. Alapvetően képes az életörömre, elfogadja önmagát, személyisége és tapasztalatai összhangját éli meg és ennek következtében viselkedése hiteles. Az autonómia megfelelő szintjét éri el, megfelelő önismeretre tesz szert, s képes másokat is reálisan észlelni. Megtanul szeretni és szeretetet elfogadni. Képes az empátiára, s jól tudja szabályozni kapcsolataiban a közelséget és a távolságot, képes az intimitás megélésére. Alkalmas arra, hogy képességei szerint teljesítsen a munkában, megfelelő módon tudjon részt venni az alkotás folyamatában. Értékrendje stabil, de nem merev. Érzelmi biztonságot alakít ki és él meg, belső erőforrásait képes megfelelő mértékben bevonni a problémák megoldásába és a stresszel szembeni megküzdésbe. Végül képes arra, hogy a rendelkezésére álló funkciókat és erőforrásokat a szükséges arányban integrálja az adott egyéni és társas helyzetnek megfelelően. A fenti optimális kívánalmakat természetesen az egészséges ember is egész élete során csupán részben tudja beteljesíteni. A segító és terápiás folyamatok különféle szinteken és módokon mozdítják eló ezen funkciók javulását, megvalósulását, komoly elakadás esetén terápia révén is, és segítenek a kívánt integráció elérésében (Pintér, 2009).

Egy teljesen másik irányból is szükséges elindulnunk. Ez a pszichoterápia nemspecifikus tényezóinek tana. A pszichoterápia kutatásának eddigi 70 esztendeje egyértelmúen kimutatta, hogy a teljesen különböző elmélettel és gyakorlattal rendelkező, tudományosan ellenőrzött pszichoterápiás iskolák közel azonos hatékonysággal képesek gyógyítani a lelki zavarokban szenvedő embert. Egyik terápiás iskola sem aratott elsöprő győzelmet. Ez a felismerés vezetett el érthető módon a pszichoterápia nemspecifikus tényezőinek tanához: feltételezhető, hogy akkor leginkább a közös elemek hatnak. Ennek középpontjába egyre inkább a Rogers-i alapattitúdök kerültek: az empátia-elfogadás-hitelesség hármasa, mivel ezek minden irányzatban pozitív korrelációkat mutattak az eredményességgel. Ez könnyedén vezetett arra a következtetésre, hogy akkor nyilván maga a kapcsolat nemspecifikus (például Frank, 1984). Rogers attitúdjeinek általános azonosítása a nemspecifikus hatással véleményünk szerint nem tartható. A specifikus és nemspecifikus hatótényezők éles kettéválasztása az orvosi modellből ered, amely remek modell a gyógyszerkísérletek területén, ahol a specifikus hatás 
jól elkülöníthetően biológiai jellegú. Esetünkben viszont a fő hatás maga is pszichológiai jellegú, így a módszerek és technikák nem tisztán érvényesülnek.

A kapcsolat kizárólagosan nemspecifikus volta nem állja meg a helyét. Igaz, bizonyára nemspecifikus a páciens elvárásaiból fakadó és a konkrét kapcsolatban realizálódó placebohatás, vagy az első találkozás és annak történései. Ugyanakkor az egyes módszerek különféle, egymástól élesen eltéró „kapcsolati ajánlatot" hordoznak magukban. A pszichoterápia sikere attól is nagymértékben függ, hogy a páciens képes-e az adott pszichoterápiás iskola által, a terapeuta közvetítésével felkínált kapcsolati ajánlat elfogadására. Véleményem szerint így a kapcsolat maga az igazán specifikus hatás, az adott módon létrejövo „terápiás szövetség” maga, amely más- és másféle lesz a különféle módszerek, technikák alkalmazása hatására.

Tehát a Rogers-i módon létrejött kapcsolat a terapeutával, segítóvel specifikus fejlesztó-gyógyító hatásokat hordozhat. S ugyanez mint nemspecifikus hatás alapja lehet másféle pszichoterápiáknak, ahol másféle specifikus kapcsolati szerveződés (pl. indulatáttételes) múködik (Pintér, 2008).

A harmadik irány, amelyból hasznos indulnunk, a segitő kapcsolati munkaformák olyan jellegzetes dimenzióinak számba vétele, amelyek látható és rejtett vonásaikat összehasonlíthatóvá teszik. Bagdy (2009) elvégezte ezt a munkát a diádikus segító helyzetre vonatkozóan, s a pszichoterápiát, önismereti munkát, tanácsadást és szupervíziót vizsgálja általa. Kiemeli és elemzi a professzionális segítő munkaformában közös elemeket, mint a kontraktuskötés valamely első interjú alapján, a segítő szakember alapattitúdjei és alapkompetenciái, stb. Közben ugyanarra a következtetésre jut, mint mi az elóbb, hogy maga a kapcsolat a fontos és nem az alkalmazott technikák. A munkaformák közötti különbözőség 9 dimenziója Bagdy szerint: a kliens szerepe, a segítő képzettségi követelményei, a kompetenciakövetelmények, a lélektani munka célja, az önismereti cél, továbbá a probléma fókusza, a tevékenység határai, a pszichológiai értelemben vett tanulás területei és formái és a közös munka kimenetele.

A fenti három meggondolás: az érett személyiség jellemzői és szintjei, a hatótényezők elemzése és vizsgálata, és a tevékenységek fenti dimenziók melletti elemzése nagy segítséget adhatnak a segítő munkaformák elkülönítéséhez. Nagyon alapos összevetések és újabb komoly kutatómunkák lennének szükségesek ahhoz, hogy valójában megtudjuk, mi zajlik az egyes tevékenységek mélyén. Csak folyamatkutatással lehetne rájönni arra, hogyan hatnak például a Rogers-i attitúdök (pl. empátiás tükrözés), vagy akár egyéb specifikus technikák (pl. deszenzitizálás, szerepcsere) a különféle munkaformákban. A mennyiségi és minőségi különbségek csak ezáltal lennének feltárhatók. Ez segíthetne igazán a kompetenciahatárok meghúzásá- 
ban is, amelyek bizonyára ebben az esetben sem lennének túl merevek. Az is kiderülhetne, hogy az érett személyiség milyen típusú és mértékú deficitjénél melyik szakma mely beavatkozása optimális.

A pszichológiai tanácsadás és a mentálhigiéné elkülönítésében alapvető, hogy az elóbbi önálló, konkrét szakma, tudásanyaga a tíz féléves pszichológiai stúdiumra épülő szakpszichológusi kompetenciarendszer. Igen jelentős a háttér elméleti tudásanyag mértéke, amely adott helyzetben mobilizálható, transzferálható. A mentálhigiéné már definíciójában interdiszciplináris, s tudásanyaga ötvözi az adott mentálhigiénés szakember eredeti szakterületén szerzett kompetenciáit a mentálhigiénés többlettudással. A szakpszichológus elsősorban egy tanácsadó központban lesz elérhetó (igaz, ez lehet iskolához, óvodához rendelt!), a mentálhigiénés szakember - kiterjesztett munkaköri feladatokkal - marad az eredeti szakmájában, az eredeti helyén, amely a társadalomban szerencsés módon bárhol lehet, „kint a terepen”. Így feltehetően a prevencióban és egészségfejlesztésben is többeket és könynyebben érhet el. Sok kliensét irányíthatja át a tanácsadó szakpszichológiai ellátásba, akiknél bármely szempontból elérte szerzett kompetenciájának határait, ugyanakkor ő is befogadó lesz az átirányításra, ha a „terepről” van szó, pl. szükséges cselekvéstámogatás, együttmúködés, közösségépítés igénye esetén. Az átirányítás a klinikai pszichológia és pszichoterápia felől és felé is kell, hogy múködjék.

A tanácsadás és a pszichoterápia elkülönítésével sok szerző alaposan foglalkozik. A tanácsadás nem minden munkaformában jelent szúkebb értelemben vett pszichológiai tanácsadást, sőt, a fogalomhasználatban létezik "mentálhigiénés tanácsadás" is, nem beszélve a módszerspecifikus tanácsadói (nem-pszichoterápiás „szakirányon” szerzett) végzettségekről, amelyekhez nem feltétlenül kell pszichológusnak lenni, de a mentálhigiénés végzettség sem kötelező hozzá.

Az alábbiakban látszólag visszatérünk a tanácsadás alapjellegzetességeinek tárgyalására, valójában most csak a fenti elkülönítés szempontjaira figyelünk, illetve azt emeljük ki kompetens hazai szerzők írásaiból.

Ritoók (2009) a tanácsadást a terápiához képest viszonylag rövid távú folyamatnak gondolja, alapvetóen egészséges személyeknek számára, amely segít a problémamegoldásban, döntésben, ösztönöz, támogat, viselkedést optimalizál. Tringer (1998), ahogy már említettük, a "gyógyító beszélgetés" kifejezés megalkotásával a tanácsadásban és terápiában közös tényezőket és azok közös oktathatóságát hangsúlyozza, ugyanakkor nem mossa egybe a kettőt, a konkrét tevékenységeket az alkalmazás kontextusa és pontos célja, valamint a segító végzettsége, tudása szerint különíti el.

Bagdy (2009) a rövid terápiák tünetcentrikusságát hangsúlyozza, míg a hosszú terápiák a személyiség múködését, sőt, struktúráját célozzák meg. 
A tanácsadás ezekkel szemben általában problémafókuszt állít a középpontba. Konkrét életeseményhez kapcsolódóan segít, betölti az önismereti igényt egy szúkebb területen, megoldást keres, facilitál. A pszichoterápia a múltban gyökerező konfliktusok feltárását és korrekciójáét tartalmazhatja, a cél a személyiség egészének reorganizációja, önismereti cél esetén is a teljes személyiségtartománnyal foglalkozik. Nyitrai (2011) igyekszik összefoglalni a különbségtételre való törekvéseket. Sokan helytelenül mennyiségi paraméterek alapján próbálkoznak az elkülönítéssel, a tanácsadás ezekben egyfajta mini terápia. A tanácsadás döntési képességet fejleszt, segít az élethelyzetek megoldásában, nincs benne beteggé minősítés, nem sugallja a múlt jelentőségét. A tanácsadásban a kliens problémáin dolgoznak, a pszichoterápiában „magán a kliensen”. Vikár és Tomcsányi (2003) szerint a pszichoterápiás szerződés és keret szigorúbb, célja egyértelmúen a gyógyítás. A pszichoterapeuta egy vagy több definitív pszichoterápiás módszert használ, azok specifikus eszköztárát tudja hatékonyan múködtetni.

A tanácsadás fogalma széles körú tevékenységrendszert takar. Célja nem vonatkozik a fenti értelemben a személyiség egészére, s nem gyógyító jellegú. A tevékenység általában sokkal kevésbé kötődik az egészségügyi ellátáshoz. A tanácsadásban sokszor több dimenzió halad együtt: a lelki segítségadás mellett szociális problémák, személyes kompetenciákkal kapcsolatos témák, szomatikus betegséggel kapcsolatos információk is teret kapnak. A többé-kevésbé jól körülírt probléma segítése a cél, konzultatív módon, közös megoldáskereséssel. Sokszor a szelf specifikus irányú erősítése a cél, például kiemelt stresszhelyzetekben (megküzdési kompetencia), vagy normatív krízisek esetén (természetesen előforduló nehéz életesemények, válságok). Az elfogadó, empátiás légkör a tanácsadás során is megteremtődik, de itt ennek nyomán kevésbé alakul ki a kliensben az a személyközpontú pszichoterápiában gyakori élmény, hogy ő szinte "saját magával beszélget”. A tanácsadás jellemző idődimenziója a jelen-jövő, és a változás motivációjának dinamikája is ebben jelentkezik (Pintér, 2009).

\section{A szakmák együttmúködése a gyakorlatban: lehetőségek és nehézségek}

A négy kiválasztott szakma közös abban, hogy segító alapdiplomára épülő posztgraduális képzés útján sajátítható el, mindegyik alapos felkészülést ad vállalt feladatában, elégséges tudományos hátteret biztosítva. Ilyen szempontból érvényes az "egy csónakban evezünk” elv. Egyéb hasonló társaikkal együtt közösen állnak szemben azokkal az álszakmákkal, amelyek a kliensek felé esetleg ügyesebben, látványosabban hirdetik magukat, köny- 
nyú terápiát, segítséget, tréninget ígérve. Sok kliensem volt előzetesen kártyavetőnél, látónál, különféle ismert-ismeretlen elnevezésú terapeutánál, akik nem kis kárt okoztak nekik. Ha mással nem, azzal, hogy az adekvát kezelések helyett vették igénybe őket. A semmire nem épülő, sehol sem akkreditált, invalid „képzések” és „végzettségek” hasonló károkat okozhatnak. Az önkormányzatok információ hiányában könnyen kiadják az engedélyt olyan egyéni vállalkozások, Bt.-k, Kft.-k számára, ahol a felsorolt cégtevékenységek között (legalább burkoltan) szakmánk számára ismeretlen és elfogadhatatlan ténykedések vannak. Ilyen perspektívában a tárgyalásunkba bevont szakmák ennek ellentétét megvalósítva közel állnak egymáshoz. Közös céljuk lehet fellépni a fenti jelenségek ellen, de ez nagyon nehéz.

Az ideális ellátást a tudományos igényú segító szakmák megfelelő együttmúködése adhatja. A valóságban jelenleg a négy szakma képviselői gyakrabban dolgoznak egyedül, mint a kívánt interdiszciplináris együttmúködésben. Mégis hangsúlyozzuk ennek jelentőségét, mint elérendő célt. Ehhez csoportdinamikai tudásra, a teamek múködési természetének ismeretére is szükség van, ezért effélét tanítanunk kellene minden társszakmában. A szakmapolitikai törekvések is vehetnének határozottabb irányt az integráció felé.

A legtöbb kliens, feltételezésem szerint, a "terepen” a mentálhigiénével fog legelőször találkozni, illetve az ennél szúkebb társadalmi hatókörú, de kirajzoltabb identitással bíró pszichológiai tanácsadással. Ha a „betegség felól" érkezve kerül az ellátó rendszerbe, klinikai szakpszichológussal, pszichiáterrel, pszichoterapeutával találkozik leginkább elsóként. Bárhogy is jön, a szakszerú első interjú alapján tudunk tervezni, s dönteni az esetleges továbbküldésről, vagy éppen a vállalásról, bárhol is találkozunk a klienssel. Ha például valaki pánikbetegségben szenved, személyiségében erősen borderline vonásokat hordoz, életközepi válságban van, s éppen elveszítette az állását, s emiatt öngyilkossági gondolatai is vannak, a segító szakember végzettsége döntő lesz abban, mi lesz a segítő kapcsolat fókusza. Természetesen az interdiszciplináris team munka tudja mindezt a legjobban megítélni. Lehet, hogy krízisintervenciót biztosítunk számára, amelyben több szakma is jártas, vagy munkatanácsadó segít neki állást keresni, vagy éppen pszichoterapeutához kerül pánikbetegsége kezelése, vagy/és személyiségstruktúrája reorganizációja érdekében.

A cél mindenképpen az, hogy mindenki a legadekvátabb ellátást kapja. A segítők hosszú távon az átirányítást piaci szempontból is nyugodtan megengedhetik maguknak, hiszen a segítség igénye óriási a társadalmunkban. Igaz, a hozzáférés lehetősége területileg és társadalmi csoportok szerint igen egyenetlen, s a finanszírozás sem egyformán megoldott. A kínálat és a kereslet is megvan tehát, a híd megteremtése a mentálhigiéné és a pszi- 
chológia közös feladata: az ismeretterjesztés, a felvilágosítás, az egészségfejlesztés növelése, s ide tartozik a nagyobb szakmapolitikai határozottság, céltudatosság, ha kell, a törvényalkotás felé is.

A fiatal szakemberek mindegyik szakmában nagy támogatást kell, hogy szerezzenek, már a szakképzések idején, s utána is folyamatosan. A képzések alatt a szakma gyakorlatának csupán egy része sajátítható el, ezért szükség van tevékenységkísérő stúdiumokra, szakmai (akár regionális) csoportokra és folyamatos szupervízióra. Jelenlegi tanítványaim, közöttük tanácsadó és klinikai szakpszichológus jelöltek, pszichoterapeuta jelölt orvosok és pszichológusok, leendő és végzett mentálhigiénés szakemberek jelentős többségükben igen motiváltak, teljesen tisztességes módon és eszközökkel küzdenek saját szakmai önmegvalósításukért és klienseikért. Határtartók, lelkesek, etikusak. Nagyon ritkán találkozom a kiskapukat keresővel, a „megúszni akarás” szándékával, lelkiismeretlen hozzáállással. Mindez, bevallom, optimistává tesz a jövőt illetően.

Ugyanakkor beszélnünk kell a nehézségekról, szakmai dilemmákról is. Ezek közül emelek ki néhány jelentősebbet az alábbiakban.

A pszichológus BA és MA diplomát szerzők száma sokszorosan gyorsabban emelkedett, mint az álláshelyeké. Az utóbbi években egyre gyakoribb, hogy pályakezdő pszichológusok (szakvizsga nélkül) egyfajta csoportpraxisokba tömörülnek és „rendelni” kezdenek, ami maximum egyfajta tanácsadási tevékenységet takarhat. A jogi lefedettséget esetleg néhány szakvizsgázott kollega jelenléte biztosítja. Jó esetben a pszichológus kollegák már járnak szakképzésbe vagy módszerspecifikus képzésekbe és annak gyakorló-szupervíziós fázisában vannak. A kliensek a forgalmasabb városokban bő keresletet jelentenek, ők pszichológiai vagy annak vélt problémáikra „pszichológust keresnek". És a megtalált szakemberek itt valóban azok is. Csak tudjuk, hogy még nem teljesen felkészültek. Természetesen vannak, remélhetőleg többségben, teljesen szabályosan múködő terápiás praxisok is.

Gyakran találkozom a terepen azzal a határátlépéssel, hogy egy mentálhigiénés képzést végzett segítő (pl. tanári alapvégzettséggel) feladja eredeti szakmáját és önálló mentálhigiénikusként kezd dolgozni, segíteni, „rendelni". Pedig tudjuk, hogy ilyen önálló szakma nincsen Magyarországon. Főképp kisebb városokban dolgozó pszichológus kollegák panaszkodnak egyre gyakrabban, hogy milyen sok klienst elvisz tőlük a helyi igen ügyes „mentálhigiénés tanácsadó".

A klinikai pszichológia és a pszichológiai tanácsadás között is sok feszültség volt az elmúlt években, épp a kompetenciahatárok bizonytalansága, azok be nem tartása vagy éppen túlzott kompetenciavédés következtében. Bár közelről ismerem e területeket, sosem láttam közöttük túlzott érdekellentétet, pláne veszélyt. A pszichológiai tanácsadás szakmai Alapprotokolljának 
(Kissné Viszket \& Mogyorósy-Révész, 2019) megjelenése is nagy segítség lehet a félreértések tisztázásában, amely beszél olyan dolgokról és rögzít olyanokat, amelyek félreérthetők voltak.

A klinikai pszichológia és pszichoterápia viszonyulása már nem ilyen egyszerú. Mindkettő történeti fejlődéséről és annak nehézséget is okozó jellegzetességeiról már írtunk a vonatkozó alfejezetekben, ezt most nem ismételjük. Gyakran említett további álláspont viszont, hogy a klinikai pszichológiai tudás a pszichoterápia egy igen jelentős részét már tartalmazza. E vélemények szerint a klinikusi képzést kellene úgy definiálni, hogy abban a pszichoterápia már benne foglaltassék. Méltatlannak tartják sokan, hogy a pszichoterápia bemenetén azonos legyen helyzetük egy szakorvossal, akár pszichiáterrel, aki képzése (orvos) és szakképzése (szakvizsga) során kevesebb alaptudást és gyakorlatot szerez.

A külföldi tapasztalatok azt mutatják, hogy a pszichoterápia szabályozása annyiféle, ahány országot vizsgálunk. Németországban például külön orvosi és pszichológusi pszichoterápia létezik, a finanszírozás kevés módszert ismer el. Ausztriában sokféle akkreditált módszer él egymás mellett és a képzés bemenete teljesen nyitott. Magyarország meglehetősen konzervatív álláspontot képviselt eddig a történeti fejlődés követésével: csak szakorvosok és (bizonyos) szakpszichológusok lehetnek pszichoterapeuták. Magam helyesnek tartanám (és ezt az álláspontomat sokszor kifejtettem), ha a pszichoterápiát, illetve a képzés bemenetét mi magunk nyitnánk meg bizonyos segító szakmák előtt, ezzel megőrizve a szabályozhatóságot és a minőségbiztosítást. Mindez segíthetne a valódi pszichoterápia „kifehérítésében".

Megemlítjük végül a módszerspecifikus képzések problematikus oldalát is. A képzések bemenete és kimenete nincs egységesen szabályozva (kivéve: akkreditált pszichoterápiás egyesületek pszichoterápiás stúdiumai). A képzőhelyek egyesületek, saját maguk által meghatározott képzési rendekkel, tartalmakkal, óraszámokkal. A módszerek elnevezései jogilag nem védettek. A kiadott oklevelek is különbözőek. A módszer gyakorlója általában alapvégzettsége és tevékenysége kiegészítéseként használja szerzett újabb tudását. Ugyanakkor itt is vannak gyakori határátlépések.

A módszerek száma jelentős, közülük azonban csak 15 akkreditált Magyarországon (az Orvosegyetemek Grémiumai által). A képzésbe jelentkezőket máshol nem mindig informálják erről, s később ez gyakran hátrányt jelent számukra. Ugyanez fordulhat elő, ha akár egy akkreditált módszert elvégzett, de nem kiképző szakember tanfolyamára jelentkeznek. Több módszerben vannak nem pszichoterapeuta végzettségú kiképzők is, az ő oktatási munkájukat a módszeren belül igen (a "tanácsadó” ágon) , de a pszichoterápiás szakképzésben (szakvizsga híján) nem fogják elfogadni. 
Mindezek arra utalnak, hogy a pályakezdő szakemberek korrekt és széleskörú informálása elengedhetetlen feladatunk. Sokan és sokszor megyünk pszichológus hallgatók vagy oktatóik meghívására olyan fórumokra, ahol a képzések tartalmi és formai jellegzetességeiről szeretnének többet tudni, ahol részletes és korrekt információt adhatunk.

\section{Kitekintés}

Lezáró fejezetünkben néhány gondolatot fogalmazunk meg a tanulmányunkba bevont, legelterjedtebb segítő szakmák fejlődésének kívánatos jövőbeli alakulásáról és feladatairól.

A pszichológiai tanácsadás volumenében és minőségében igen jelentősen fejlődött az elmúlt évtizedekben. A képzés egyre gyakorlatorientáltabbá vált, mérhető kompetenciarendszer fejlesztést ad. Az ELTE PPK Pszichológiai Tanácsadás Tanszéke és a Magyar Pszichológiai Társaság Tanácsadás Pszichológia szekciója komoly erófeszítéseket tesz a végzett szakemberek összefogása, továbbfejlesztése érdekében. Nagy lépés az Alapprotokoll elkészítése, a tágabb szakma felé is. Ami a jövő feladata: szükséges az élesebb kontúrral bíró szakmapolitikai munka, a közös célok megfogalmazása. Ilyen lehet a pszichológiai tanácsadó hálózat, mint egységes ellátó rendszer megteremtése. Amennyiben a pszichoterápiás képzésben való részvétel lehetősége is cél, mindenképpen egy orvosegyetemmel való képzési együttmúködést látok szükségesnek és a képzésben a pszichoterapeuta végzettségú oktatók arányának növelését. A pszichoterápiás szakma mindig azzal érvel, hogy a ráépített szakvizsgás képzések bemenete medicinális alapszakvizsga kell, hogy legyen. Ahhoz pedig, hogy ilyen irányba elmozduljunk, hallgatóinknak medicinális, pl. az egészségügy keretében/határmezsgyéjén szervezett gyakorlóhelyekre van szükségük.

A mentálhigiéné az interdiszciplinaritás jobb gyakorlati megvalósításával fejlődhetne jelentősen. A team munka mint elv további hangsúlyozása helyett feltételei megteremtésével, kiharcolásával lehetne intenzíven foglalkozni. Ugyanakkor meg kellene fékezni azon egyéni törekvéseket, amelyekben a végzett mentálhigiénés szakemberek "rendelőt” nyitnak és burkolt pszichoterápiás magángyakorlatot folytatnak, amelyre tényleg nincsenek meg a kompetenciáik és természetesen a jogi háttér sem.

A klinikai (és mentálhigiénés) szakpszichológia a bennfoglalt pszichoterápiás kompetenciák jobb definiálását tehetné meg a jövőben. Feltehetően az alappszichoterápiás tevékenységeket kellene kiterjeszteni, természetesen akkor a képzésben is. Véleményem szerint helyes, ha a ráépített pszichoterapeuta képzés rendszere fennmarad, ahol az orvos és pszichológus jogi szempont- 
ból is azonos helyzetból lehetnek partnerek. A szabályozás, a tartalom, a bemenet lehet eltéró a mostanitól. Itt a már megszerzett tudáselemek, kreditek beszámíthatóságának növelése lehet cél.

A pszichoterápia hazai fejlődésében jó lenne megtartani a sokszínúséget, a módszerek bizonyos szempontú egyenértékúségét. Fontos az egységes szakmai fellépés „kifelé”, valamint az orvosegyetemek pszichoterápiás grémiumaival való jó, da határozott kontúrokkal bíró együttmúködés fenntartása. Az egészségügyi finanszírozási rendszerben bizonyára harcolni kell a pszichoterápia pontszámainak növeléséért, hiszen a pszichoterápia az állami egészségügyben ma alig képes fenntartani magát.

A négy segitő társszakma együttmüködésében pedig az interdiszciplináris team munka elómozdítása lehet cél, amelyben a képzett pszichológus, orvos, és más segítő foglalkozású valóban együtt dolgozik, képződik tovább, kap szupervíziót. Ha az ellátó rendszerek önmagukban jobban kirajzolódnának, a társszakmák közötti alapvetően szükséges átirányítás útjai is egyértelmúbbek lehetnének.

S minden területen, külön-külön, de együtt is szükség van újabb kutatásokra, doktori munkákra (akár ezt is teamekben), hatékonyságvizsgálatokra. A jövő kutatásaiban remélhetőleg nagy szerep fog jutni a kapcsolati minták, a terápiákban és segító intervenciókban valóban közös elemek vizsgálatának és az irányzattól független folyamatkutatásnak. Ez utóbbiban a segító szakmákban előforduló valamennyi lehetséges (bármely irányzat által deklarált) hatótényezőt valamennyi irányzat folyamatában vizsgálnánk, párhuzamosan az eredményesség mutatóival. A közös nevező feltehetően mindenképpen a segítő/terápiás kapcsolatban magában van. Benne a segító kapcsolatok tudásanyaga mint egységes tudomány lehetősége tárul fel, amely tudományos alapon őrizheti meg a gyakorlat meglévő, változatos megjelenésú szépségét, kívánatos sokszínúségét.

\section{Nyilatkozat érdekütközésről}

A szerző ezúton kijelenti, hogy esetében nem állnak fenn érdekütközések.

\section{Irodalom}

Bagdy, E., \& Túry, F. (Szerk.) (2005). A klinikai és mentálhigiéniai szakpszichológia szakmai protokollja (második, átdolgozott változat). Budapest: Klinikai Pszichológiai Szakmai Kollégium

Bagdy, E. (2009). Pszichoterápia, tanácsadás, szupervízió, coaching: azonosságok és különbségek. In: É. Kulcsár (Szerk.), Tanácsadás és terápia (53-77). Budapest: Eötvös Kiadó Buda, B. (1998). Elméletés alkalmazás a mentálhigiénében. Budapest: OAI és Támasz Alapítvány 
Frank, J. D. (1984). Therapeutic components of all psychotherapies. In J.M. Meyers (Ed.): Cures by psychotherapy (15-27). New York: Prager

Grezsa, F. (2003). Mentálhigiénés szakirányú továbbképzési szak a Magyar Testnevelési Egyetemen. In: T. Tomcsányi, F. Grezsa, F., \& I. Jelenits (Szerk.), Tanakodó. A mentálhigiéné elmélete, a mentálhigiénés képzés, mentálhigiéné az emberek szolgálatában (105-122). Budapest: Semmelweis Egyetem TF, Párbeszéd Alapítvány, Híd Alapítvány

Harmatta, J., Bagotai, T., Kurimay, T., Pintér, G., \& Vértes, G. (Szerk.) (2005). A pszichoterápiás módszerek szakmai protokollja. Budapest: Klinikai Pszichológiáért Alapítvány. Letöltve: 2019.03.03-án: https://www.scribd.com/document/243482208/PszichoterapiasModszerek-Protokollja

Ittzés, G. (Szerk.) (2013). Cura mentis - Salus Populi. Mentálhigiéné a társadalom szolgálatában. Budapest: Semmelweis Egyetem EKK Mentálhigiéné Intézet

Kissné Viszket, M., \& Kiss, P. (2016). A tanácsadó szakpszichológus kompetenciái. In: M. Kissné Viszket, Zs. Puskás-Vajda, J. Rácz, \& V. Tóth (Szerk.), A pszichológiai tanácsadás perspektívái (229-245). Budapest: L'Harmattan

Kissné Viszket, M., \& Mogyorósy-Révész, Zs. (2017). Pszichológiai tanácsadás szakmai alapprotokoll - A tanácsadói folyamat. Alkalmazott pszichológia, 17(4), 45-66.

Kissné Viszket, M., \& Mogyorósy-Révész, Zs. (2019). A Pszichológiai Tanácsadás Szakmai Protokollja. Alapprotokoll. Budapest: ELTE Eötvös Kiadó. Letöltve: 2019. 07. 08-án. http:/ / www.eltereader.hu/media/2019/06/Kissne_Viszket_Pszich_tanacsadas_WEB.pdf

Kopp, M., \& Buda, B. (2001). Magatartástudományok. Budapest: Medicina Könyvkiadó

Kozékiné Hammer, Zs. (2016). A pszichológiai tanácsadás lehetséges modelljei. In M. Kissné Viszket, Zs. Puskás-Vajda, J. Rácz, \& V. Tóth (Szerk.), A pszichológiai tanácsadás perspektívái (59-76). Budapest: L'Harmattan Kiadó

Nyitrai, E. (2011). A tanácsadás alapjai. In N. Császár Nagy, Zs. Demetrovics, \& A. Vargha (Szerk.), A klinikai pszichológia horizontja (275-288). Budapest: KGRE \& L'Harmattan Kiadó

Pintér, G. (2005). A klinikai szakpszichológia részvétele a mentálhigiéné interdiszciplináris tevékenységrendszerében. In: E. Bagdy, \& F. Túry (Szerk.), A klinikai és mentálhigiéniai szakpszichológia szakmai protokollja (második, átdolgozott változat) (275-283). Budapest: Klinikai Pszichológiai Szakmai Kollégium

Pintér, G. (2008). Kutatás. In G. Szőnyi, \& J. Füredi (Szerk.), A pszichoterápia tankönyve (2., átdolgozott kiadás) (522-545). Budapest: Medicina

Pintér, G. (2009). Személyközpontú pszichoterápia és tanácsadás. In É. Kulcsár (Szerk.), Tanácsadás és terápia (79-110). Budapest: Eötvös Kiadó

Pintér, G. (1993) (Szerk.). Pszichoterápia. Módszerspecifikus irányzatok. Psychiatria Hungarica. Tematikus szám.

Ritoók, M., \& Pintér, G. (1987). A csoportos pályaválasztási tanácsadás alkalmazásának lehetőségei a személyiség fejlesztésében. Pályaválasztás, 2, 33-35.

Ritoók, M. (2003). A mentálhigiénés konzultáció/tanácsadás. In T. Tomcsányi, F. Grezsa, \& I. Jelenits (Szerk.), Tanakodó. A mentálhigiéné elmélete, a mentálhigiénés képzés, mentálhigiéné az emberek szolgálatában (69-72). Budapest: Semmelweis Egyetem TF, Párbeszéd Alapítvány, Híd Alapítvány

Ritoók, M. (2011). Tanácsadás az iskolában. In N. Császár Nagy, Zs. Demetrovics, \& A. Vargha (Szerk.), A klinikai pszichológia horizontja (289-304). Budapest: KGRE - L'Harmattan Kiadó

Ritoók, M. (2009). Új tendenciák a pszichológiai tanácsadás fejlődésében. In É. Kulcsár (Szerk.), Tanácsadás és terápia (221-254). Budapest: Eötvös Kiadó

Rogers, C.R. (1942). Counseling and Psychotherapy. Boston: Houghton, Mifflin 
Tomcsányi, T., Grezsa, F., \& Jelenits, I. (Szerk.) (2003). Tanakodó. A mentálhigiéné elmélete, a mentálhigiénés képzés, mentálhigiéné az emberek szolgálatában. Budapest: Semmelweis Egyetem TF, Párbeszéd Alapítvány, Híd Alapítvány

Tringer, L. (1998). A gyógyító beszélgetés. Budapest: Haynal Imre Egészségtudományi Egyetem

Urbán, R. (2017). Az egészségpszichológia alapjai. Budapest: ELTE Eötvös Kiadó Kft.

Vikár, Gy., \& Tomcsányi, T. (2003). A mentálhigiénés segítő kapcsolat és a pszichoterápiás kapcsolat. In T. Tomcsányi, F. Grezsa, \& I. Jelenits (Szerk.), Tanakodó. A mentálhigiéné elmélete, a mentálhigiénés képzés, mentálhigiéné az emberek szolgálatában (80-90). Budapest: Semmelweis Egyetem TF, Párbeszéd Alapítvány, Híd Alapítvány

\section{Professions joining forces for mental health}

\section{PINTÉR, GÁBOR}

In our study we are going to explore four professions related to each other by their importance in assisting people with mental care: psychological counselling, mental health care, clinical psychology and psycho-therapy. The professionals working in these fields are the counselling psychologist, the mental health care provider, the clinical psychologist and the psycho-therapist (a specially trained expert or physician). In our study we are going to outline the specifics of the given discipline: its legal background, the expected skills and competencies, the main areas of activity and the required specific training systems of education. We will consider and compare possible issues related to different problems and tasks, study the dimensions when dealing with different levels of maturity of the personality, the impact of the various interactions in care and the implications of different approaches. We will focus on the specifics of counselling and mental health care as well as on the differences between counselling and psycho-therapy. Finally we will have a look at the current trends of these professions and at the ways they are expected to evolve in the future, trying to understand what the possibilities are for us to make the most of the synergy born as a result of their combined impacts.

Keywords: counseling, mental health, clinical psychology, psychotherapy, helping competencies, fields of helping activities, legal background, education systems, interdisciplinary cooperation

A cikk a Creative Commons Attribution 4.0 International License (https:/ / creativecommons.org/ licenses/by/4.0/) feltételei szerint publikált Open Access közlemény, melynek szellemében a cikk bármilyen médiumban szabadon felhasználható, megosztható és újraközölhető, feltéve, hogy az eredeti szerző és a közlés helye, illetve a CC License linkje és az esetlegesen végrehajtott módosítások feltüntetésre kerülnek. (SID_1) 